\title{
Pengaruh Aplikasi Asam Humat dan Pemupukan Fosfat terhadap Populasi dan Biomassa Cacing Tanah pada Pertanaman Jagung (Zea mays L.) di Tanah Ultisol
}

\author{
Effect of Humic Acid Application and Phosphate Fertilization on Earthworm \\ Populations and Biomass in Corn (Zea mays L.) in Ultisol Soil
}

\author{
Bagas Sadewa ${ }^{1 *}$, Ainin Niswati ${ }^{1}$, Septi Nurul Aini ${ }^{1}$, Sri Yusnaini ${ }^{1}$ \\ 1 Jurusan Agroteknologi, Fakultas Pertanian, Universitas Lampung. \\ JI. Sumantri Brojonegoro 1, Bandar Lampung, 35145, Lampung, Indonesia \\ *Email: bagassadewa7@gmail.com
}

\author{
Disubmit: 11 September 2019 Direvisi: 19 Desember 2019 Diterima: 17 Januari 2020
}

\begin{abstract}
Abstrak: Tujuan penelitian ini untuk mempelajari pengaruh aplikasi asam humat dan pemupukan fosfat terhadap populasi dan biomassa cacing tanah serta mempelajari interaksi antara dua perlakuan yang diberikan. Penelitian ini dilaksanakan pada Desember 2018 sampai April 2019 di Kebun Percobaan Badan Pengkajian Teknologi Pertanian (BPTP) Natar. Perlakuan disusun secara faktorial dalam Rancangan Acak Kelompok (RAK) disusun secara faktorial dengan dua faktor dan diulang sebanyak 3 kali sebagai kelompok. Faktor pertama adalah asam humat (tanpa aplikasi asam humat, asam humat $15 \mathrm{~kg} \mathrm{ha}^{-1}$, asam humat $30 \mathrm{~kg} \mathrm{ha}^{-1}$ ), sedangkan faktor kedua adalah pemupukan fosfat (tanpa pupuk TSP, pupuk TSP $100 \mathrm{~kg} \mathrm{ha}^{-1}$, pupuk TSP $200 \mathrm{~kg} \mathrm{ha}^{-1}$, pupuk TSP $300 \mathrm{~kg}$ $\left.\mathrm{ha}^{-1}\right)$. Hasil penelitian menunjukan bahwa aplikasi asam humat berpengaruh nyata terhadap populasi cacing tanah pada pengamatan fase vegetatif maksimum (50 HST) dan sebelum panen (90 HST). Populasi cacing tanah tanah pada pengamatan 50 HST dengan perlakuan tanpa aplikasi asam humat lebih tinggi (4 ekor) dibandingkan dengan perlakuan aplikasi asam humat $15 \mathrm{~kg} \mathrm{ha}^{-1}$ (2 ekor) dan $30 \mathrm{~kg} \mathrm{ha}^{-1}$ (1 ekor). Selanjutnya, populasi cacing tanah pada pengamatan $90 \mathrm{HST}$ dengan perlakuan aplikasi asam humat $30 \mathrm{~kg} \mathrm{ha}^{-1}$ lebih tinggi (56 ekor) dibandingkan dengan perlakuan asam humat $15 \mathrm{~kg} \mathrm{ha}^{-1}$ (37 ekor) dan tanpa aplikasi asam humat (25 ekor). Pemupukan fosfat berpengaruh nyata terhadap populasi dan biomassa cacing tanah pada pengamatan fase vegetatif maksimum (50 HST). Populasi cacing tanah pada pengamatan $50 \mathrm{HST}$ dengan perlakuan pupuk TSP $300 \mathrm{~kg} \mathrm{ha}^{-1}$ lebih tinggi (5 ekor) dibandingkan dengan perlakuan pupuk TSP $200 \mathrm{~kg} \mathrm{ha}^{-1}$ (1 ekor), pupuk TSP 100 $\mathrm{kg} \mathrm{ha}^{-1}$ (1 ekor) dan tanpa pupuk TSP (1 ekor). Populasi cacing tanah meningkat sejalan dengan pertumbuhan tanaman jagung. Identifikasi cacing tanah pada penelitian ini menunjukkan bahwa jenis cacing tanah tergolong genus Pontoscolex sp. Cacing tanah genus Pontoscolex sp. termasuk dalam famili Glossoscolicidae, cacing ini memiliki ciri-ciri klitelum yang terletak pada segmen $\mathrm{ke}^{-1} 4$, memiliki setae dengan pola lumbrisin, dan tipe prostomium yaitu prolobus.
\end{abstract}

Kata kunci: Cacing Tanah, Glossoscolicidae, Pontoscolex sp., Pupuk TSP.

Abstract:The purpose of this study was to study the effect of application of humic acid and phosphate fertilization on earthworm populations and biomass and study the interactions between the two treatments given. The research was carried out in December 2018 to April 2019 in the Experimental Garden of the Agricultural Technology Assessment Agency (BPTP) Natar. The treatments were factorially arranged in a Randomized Block Design (RCBD) with two factors and repeated 3 times. The first factor is humic acid (without the application of humic acid, humic acid $15 \mathrm{~kg} \mathrm{ha}^{-1}$, humic acid $30 \mathrm{~kg} \mathrm{ha}^{-1}$ ), while the second factor is phosphate fertilizer (without TSP fertilizer, TSP fertilizer $100 \mathrm{~kg} \mathrm{ha}^{-1}$, TSP fertilizer $200 \mathrm{~kg} \mathrm{ha}^{-1}$, fertilizer TSP $\left.300 \mathrm{~kg} \mathrm{ha}^{-1}\right)$. The results showed that the application of humic acid significantly affected the population of earthworms in the observation of the maximum vegetative phase (50 day after planting (DAP)) and before harvest (90 DAP). The population of earthworms in the observation of 50 DAP with treatment without the application of humic acid was higher (4 tails) than the treatment of humic acid application of $15 \mathrm{~kg} \mathrm{ha}^{-1}$ (2 tails) and $30 \mathrm{~kg} \mathrm{ha}^{-1}$ (1 tails). Furthermore, the earthworm population observed at 90 DAP with $30 \mathrm{~kg} \mathrm{ha}^{-1}$ humic acid application treatment was higher (56 tails) than $15 \mathrm{~kg} \mathrm{ha}^{-1}$ humic acid treatment (37 tails) and without humic acid application (25 tails). Phosphate fertilization significantly affected the population of earthworms in the observation of the maximum vegetative phase (50 DAP). Earthworm population at 50 DAP with $300 \mathrm{~kg} \mathrm{ha}^{-1}$ TSP fertilizer treatment was higher (5 tails) than $200 \mathrm{~kg} \mathrm{ha}^{-1}$ TSP fertilizer (1 tails), $100 \mathrm{~kg} \mathrm{ha}^{-1}$ TSP fertilizer (1 tails), and without TSP fertilizer (1 tails). Earthworm populations and biomass increase in line with the growth of corn plants. The identification of earthworms in this study shows that the type of earthworm belongs to the genus Pontoscolex sp. The earthworm of the genus Pontoscolex sp. belongs to the family Glossoscolicidae, this worm has the characteristics of a clitelum which is located in the 14th segment, has a setae with a lumbrisin pattern, and the prostomium type is prolobus.

Keywords: Earthworms, Glossoscolicidae, Pontoscolex sp., TSP Fertilizer. 


\section{PENDAHULUAN}

Tanah Ultisol merupakan tanah masam yang umumnya sudah mengalami pelapukan tingkat lanjut, sehingga tanah ini memiliki tingkat kesuburan yang rendah. $\mathrm{Hal}$ tersebut dicirikan dengan nilai $\mathrm{pH}$ rendah, kandungan $\mathrm{C}$-organik yang rendah, kandungan unsur hara $\mathrm{N}$ total, $\mathrm{K}$ total, $\mathrm{P}$ tersedia, dan KTK tanah sangat rendah serta kandungan Al cukup tinggi. Selain itu, sifat fisik tanah dicirikan dengan kerapatan isi (bulk density) tanah cukup tinggi dengan ruang pori total (RPT) dan pori air tersedia (PAT) tergolong rendah (Muchtar, 2015).

Salah satu masalah pada tanah Ultisol adalah memiliki kandungan bahan organik yang rendah. Oleh karena itu, perlu upaya untuk menambah bahan organik di dalam tanah sebelum usaha budidaya tanaman dilakukan. Penambahan asam humat merupakan salah satu alternatif untuk meningkatkan kandungan bahan organik di dalam tanah. Pemberian asam humat pada permukaan tanah Ultisol (15 L ha $^{-1}$ ) dapat meningkatkan $\mathrm{pH}$ ( $\mathrm{pH}$ awal 5,74 menjadi 5,77), kandungan C-organik meningkat (0,28\%) (Ihdaryanti, 2011). Selain itu, penambahan bahan organik berupa asam humat juga dimaksudkan untuk meningkatkan efisiensi pemupukan yang telah dilakukan, sehingga produksi tanaman optimal. Pemberian asam humat $\left(15 \mathrm{~L} \mathrm{ha}^{-1}\right)$ dapat meningkatkan serapan unsur hara $\mathrm{N}(0,8 \%)$ dan $\mathrm{P}(0,02 \%)$ dibandingkan dengan kontrol (Dewi, 2014).

Permasalahan tanah Ultisol lainnya adalah rendahnya unsur hara $\mathrm{P}$, karena pada tanah masam dengan $\mathrm{pH}$ rendah menyebabkan unsur $\mathrm{P}$ terikat oleh $\mathrm{Al}$ dan Fe. Unsur $P$ merupakan salah satu unsur hara makro yang sangat dibutuhkan oleh tanaman, namun sebagian besar pupuk fosfor yang diberikan ke dalam tanah masam tidak dapat optimal digunakan oleh tanaman. Hal ini disebabkan karena pada tanah Ultisol memiliki nilai $\mathrm{pH}$ yang rendah, sehingga menyebabkan adanya reaksi antara unsur $\mathrm{P}$ dengan unsur-unsur logam di dalam tanah seperti Al dan Fe, sehingga nilai efisiensi pemupukan fosfor menjadi rendah (Maulana, Sarno dan Nurmiaty, 2014). Salah satu solusi untuk mengatasinya adalah dengan penambahan unsur hara melalui pemupukan pupuk Fosfat.

Hasil-hasil penelitian mengemukakan bahwa untuk meningkatkan kesuburan tanah dapat digunakan asam humat yang merupakan suatu molekul kompleks yang terdiri atas kumpulan berbagai macam bahan organik yang berasal dari residu hasil dekomposisi tanaman dan hewan. Sebagian besar asam humat diperoleh dari ekstraksi bahan leonardite atau lignit (Tan, 2014). Maka dari itu, dapat diartikan asam humat dapat digunakan sebagai bahan pembenah tanah. Selain akan memperbaiki sifat fisik dan kimia tanah, pemberian asam humat kedalam tanah diharapkan dapat memperbaiki juga sifat biologi tanah. Demikian dengan pemberian pupuk $\mathrm{P}$ dengan dosis berbeda-beda akan mempengaruhi produksi tanaman yang diharapkan dapat memperbaiki sifat biologi tanah.

Salah satu indikator biologi tanah yang sangat penting adalah populasi dan biomassa cacing tanah. Tingginya kandungan bahan organik pada tanah membuat populasi dan biomassa cacing tanah cenderung lebih tinggi karena bahan organik memberikan nutrisi bagi cacing tanah (Sari et al. 2015). Aplikasi bahan organik yaitu mulsa bagas dapat membuat pertumbuhan cacing tanah lebih optimal (Salamah et al. 2016). Selanjutnya, pemberian berbagai dosis pemupukan $P$ memberikan respon positif terhadap tanaman jagung (Zea mays L.) dan berpengaruh nyata terhadap tinggi tanaman dan bobot kering tanaman (Fahmi et al. 2009). Apabila pemupukan dilakukan secara optimal pada tanaman tersebut, diharapkan peningkatan biomassa tanaman dapat sejalan dengan peningkatan populasi dan biomassa cacing tanah. 
Penelitian ini bertujuan untuk mempelajari pengaruh aplikasi asam humat terhadap populasi dan biomassa cacing tanah pada pertanaman jagung di tanah Ultisol, mempelajari pengaruh pemupukan fosfat terhadap populasi dan biomassa cacing tanah pada pertanaman jagung di tanah Ultisol, mempelajari interaksi antara aplikasi asam humat dan pemupukan fosfat terhadap populasi dan biomassa cacing tanah pada pertanaman jagung di tanah Ultisol, dan mempelajari hubungan antara $\mathrm{pH}$ tanah, dan suhu tanah, kadar air tanah,C-organik tanah, dan produksi tanaman jagung terhadap populasi dan biomassa cacing tanah pada pertanaman jagung di tanah Ultisol.

\section{METODE PENELITIAN}

Penelitian ini akan dilaksanakan di Kebun Percobaan Badan Pengkajian Teknologi Pertanian (BPTP) Natar dari bulan Desember 2018- April 2019. Pengambilan sampel cacing tanah dilakukan pada saat tanaman jagung berumur 14 HST, 50 HST, dan 90 HST menggunakan metode pengambilan dengan tangan (hand sorting), kemudian dilanjutkan menggunakan larutan Mustard. Analisis populasi dan biomassa cacing tanah dilakukan di Laboratorium Biologi Tanah dan analisis sifat kimia tanah dilakukan di Laboratorium IImu Tanah Fakultas Pertanian Universitas Lampung.

Alat yang digunakan dalam penelitian ini adalah mikroskop, kuadran ukuran 50 $\mathrm{cm} \times 50 \mathrm{~cm}$, termometer, timbangan analitik, ember, tissue, kantung plastik, oven, $\mathrm{pH}$ meter, tembilang, botol film, aluminium foil, timbangan, ayakan $2 \mathrm{~mm}$, cangkul, alat tulis dan alat laboratorium lainnya. Bahan yang digunakan adalah asam humat komersial, alkohol, benih jagung BISI 18, pupuk TSP, Mustard, pupuk dasar Urea dan $\mathrm{KCl}$.

Penelitian ini dirancang menggunakan rancangan acak kelompok (RAK) yang disusun secara faktorial dengan dua faktor dan diulang sebanyak 3 kali sebagai kelompok. Faktor pertama adalah aplikasi asam humat $(\mathrm{H})$, yaitu tanpa aplikasi asam humat $(\mathrm{H} 0)$, aplikasi asam humat $15 \mathrm{~kg} \mathrm{ha}^{-1}(\mathrm{H} 1)$, dan aplikasi asam humat 30 $\mathrm{kg} \mathrm{ha}^{-1}(\mathrm{H} 2)$. Faktor kedua adalah pemupukan Fosfor (P) yang dibagi menjadi 4 taraf dosis yaitu tanpa pupuk TSP (P0), pupuk TSP $100 \mathrm{~kg} \mathrm{ha}^{-1}(\mathrm{P} 1)$, pupuk TSP $200 \mathrm{~kg}$ $\mathrm{ha}^{-1}$ (P2), dan pupuk TSP $300 \mathrm{~kg} \mathrm{ha}^{-1}$ (P3). Tanaman indikator yang ditanami pada lahan penelitian adalah tanaman jagung varietas BISI 18.

Data yang diperoleh diuji homogenitas ragamnya dengan Uji Bartlett, aditifitas data diuji dengan Uji Tukey. Jika asumsi terpenuhi maka data dianalisis dengan sidik ragam. Apabila terdapat pengaruh perlakuan, data akan diuji dengan Uji Beda Nyata Jujur (BNJ) pada taraf 5\%. Untuk mengetahui hubungan antara C-organik, $\mathrm{pH}$, suhu, kadar air tanah, dan produksi jagung dengan populasi dan biomassa cacing tanah dilakukan uji korelasi.

\section{HASIL DAN PEMBAHASAN}

Hasil penelitian menunjukkan bahwa aplikasi asam humat berpengaruh nyata terhadap populasi cacing tanah pada pengamatan 50 HST dan 90 HST. Selanjutnya, pemupukan fosfat berpengaruh nyata terhadap populasi cacing tanah pada pengamatan 50 HST (Tabel 1). Populasi cacing tanah lebih tinggi pada lahan tanpa aplikasi asam humat $(\mathrm{HO})$ dibanding lahan dengan aplikasi asam humat pada 
pengamatan 50 HST (Tabel 2). Belum berpengaruhnya aplikasi asam humat terhadap peningkatan populasi cacing tanah diduga karena waktu pengamatan yang relatif singkat belum mampu memberikan perubahan terhadap sifat-sifat tanah pada lahan penelitian, sehingga lingkungan hidup cacing tanah belum terpenuhi dengan baik.

Tabel 1. Ringkasan hasil analisis ragam pengaruh aplikasi asam humat dan pemupukan fosfat terhadap populasi dan biomassa cacing tanah pada pengamatan $14 \mathrm{HST}, 50 \mathrm{HST}$, dan 90 HST.

\begin{tabular}{|c|c|c|c|c|c|c|}
\hline \multirow{3}{*}{ Perlakuan } & \multicolumn{6}{|c|}{ Rata-Rata Populasi dan Biomassa Cacing Tanah } \\
\hline & \multicolumn{3}{|c|}{ Populasi Cacing Tanah } & \multicolumn{3}{|c|}{ Biomassa Cacing Tanah } \\
\hline & $\begin{array}{c}14 \\
\text { HST }\end{array}$ & 50 HST & 90 HST & $14 \mathrm{HST}$ & 50 HST & 90 HST \\
\hline \multicolumn{4}{|c|}{ 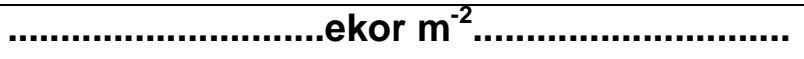 } & \multicolumn{3}{|c|}{ 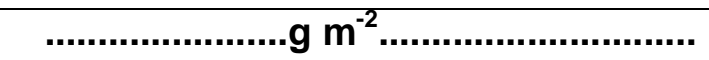 } \\
\hline $\mathrm{H}_{0} \mathrm{P}_{0}$ & $9(2)$ & $3(1)$ & $48(7)$ & $0,40(0,92)$ & $0,09(0,99)$ & $2,91(1,80)$ \\
\hline $\mathrm{H}_{0} \mathrm{P}_{1}$ & $19(2)$ & $0(1)$ & $41(6)$ & $0,94(1,13)$ & $0,00(0,71)$ & $0,77(1,12)$ \\
\hline $\mathrm{H}_{0} \mathrm{P}_{2}$ & $3(1)$ & $3(1)$ & $19(4)$ & $0,07(0,75)$ & $0,04(0,97)$ & $0,59(1,03)$ \\
\hline $\mathrm{H}_{0} \mathrm{P}_{3}$ & $1(1)$ & $12(2)$ & $43(6)$ & $0,20(0,82)$ & $0,10(1,17)$ & $4,71(2,08)$ \\
\hline $\mathrm{H}_{1} \mathrm{P}_{0}$ & $8(2)$ & $1(1)$ & $21(5)$ & $0,20(0,83)$ & $1,06(0,89)$ & $0,51(1,00)$ \\
\hline $\mathrm{H}_{1} \mathrm{P}_{1}$ & $3(1)$ & $0(1)$ & $43(6)$ & $0,05(0,74)$ & $0,00(0,71)$ & $1,17(1,28)$ \\
\hline $\mathrm{H}_{1} \mathrm{P}_{2}$ & $5(2)$ & $1(1)$ & $9(3)$ & $0,19(0,83)$ & $0,05(0,84)$ & $0,16(0,81)$ \\
\hline $\mathrm{H}_{1} \mathrm{P}_{3}$ & $5(2)$ & $4(1)$ & $28(4)$ & $0,17(0,82)$ & $1,31(1,01)$ & $1,37(1,22)$ \\
\hline $\mathrm{H}_{2} \mathrm{P}_{0}$ & $5(1)$ & $0(1)$ & $31(5)$ & $0,53(0,95)$ & $0,00(0,71)$ & $0,49(0,98)$ \\
\hline $\mathrm{H}_{2} \mathrm{P}_{1}$ & $9(2)$ & $4(1)$ & $76(9)$ & $0,40(0,92)$ & $1,32(0,89)$ & $2,39(1,65)$ \\
\hline $\mathrm{H}_{2} \mathrm{P}_{2}$ & $9(2)$ & $0(1)$ & $79(8)$ & $0,50(0,98)$ & $0,00(0,71)$ & $3,89(2,02)$ \\
\hline $\mathrm{H}_{2} \mathrm{P}_{3}$ & $3(1)$ & $1(1)$ & $39(6)$ & $0,07(0,75)$ & $0,05(0,84)$ & $1,32(1,31)$ \\
\hline $\begin{array}{c}\text { Sumber } \\
\text { Keragaman }\end{array}$ & \multicolumn{6}{|c|}{ F Hitung dan Signifikan } \\
\hline $\mathrm{H}$ & 0,03 tn & $4,14^{*}$ & 3,69 * & 0,76 tn & 0,39 tn & $2,54 \mathrm{tn}$ \\
\hline $\mathrm{P}$ & $0,81 \mathrm{tn}$ & 4,64 * & $1,30 \mathrm{tn}$ & 0,59 tn & 0,83 th & $0,51 \mathrm{tn}$ \\
\hline $\mathrm{H} \times \mathrm{P}$ & $1,38 \mathrm{tn}$ & $2,31 \mathrm{tn}$ & $1,21 \mathrm{tn}$ & 0,82 tn & $1,34 \mathrm{tn}$ & 2,46 tn \\
\hline
\end{tabular}

Keterangan : $\mathrm{H}_{0}=$ tanpa asam humat; $\mathrm{H}_{1}=$ aplikasi asam humat $15 \mathrm{~kg} \mathrm{ha}^{-1} ; \mathrm{H}_{2}=$ aplikasi asam humat $30 \mathrm{~kg} \mathrm{ha}^{-1} ; \mathrm{P}_{0}=$ tanpa pupuk TSP; $P_{1}=$ pupuk TSP $100 \mathrm{~kg} \mathrm{ha}^{-1} ; \mathrm{P}_{2}$ $=$ pupuk TSP $200 \mathrm{~kg} \mathrm{ha}^{-1} ; \mathrm{P}_{3}=$ pupuk TSP $300 \mathrm{~kg} \mathrm{ha}^{-1} ; \mathrm{H}=$ aplikasi asam humat; $\mathrm{P}=$ pemupukan fosfat; $\mathrm{H} \times \mathrm{P}=$ interaksi antara aplikasi asam humat dan pemupukan fosfat; tn = tidak berpengaruh nyata pada taraf $5 \% ;{ }^{*}=$ berpengaruh nyata pada taraf $5 \%$; angka dalam kurung menunjukkan nilai transformasi $(\sqrt{x}+0,5)$.

Tabel 2. Hasil uji BNJ taraf 5\% pengaruh aplikasi asam humat terhadap populasi cacing tanah pada pengamatan 50 HST di pertanaman jagung (Zea mays L.).

\begin{tabular}{cc}
\hline Perlakuan & Populasi Cacing Tanah (ekor $\left.\mathbf{m}^{-2}\right)$ \\
\hline Tanpa aplikasi asam humat $\left(\mathrm{H}_{0}\right)$ & $4(1,3)$ a \\
Aplikasi asam humat $15 \mathrm{~kg} \mathrm{ha}^{-1}\left(\mathrm{H}_{1}\right)$ & $2(1,1)$ ab \\
Aplikasi asam humat $30 \mathrm{~kg} \mathrm{ha}^{-1}\left(\mathrm{H}_{2}\right)$ & $1(0,9) \mathrm{b}$ \\
\hline BNJ $5 \%$ & 0,3 \\
\hline Keterangan : Angka yang diikuti oTeh huruf yang sama tidak berbeda nyata dengan uji BNJ \\
pada taraf 5\%; angka dalam kurung menunjukkan nilai transformasi $(\sqrt{x}+0,5)$. \\
Sementara itu, pada pengamatan 90 HST, populasi cacing tanah lebih tinggi \\
pada lahan dengan perlakuan aplikasi asam humat dibandingkan dengan tanpa
\end{tabular}


pemberian asam humat (Tabel 3). Hal ini diduga terjadi karena tajuk tanaman yang semakin luas dan seresah dari tanaman jagung yang kering jatuh ke tanah berperan sebagai sumber bahan organik sehingga kondisi lingkungan mikro pada lahan penelitian menjadi ideal bagi cacing tanah. Peningkatan jumlah populasi cacing tanah merupakan indikasi dari pertumbuhan dan perkembangan cacing tanah yang baik karena mendapatkan nutrisi yang cukup dari bahan organik yang diberikan di dalam tanah serta kondisi yang sesuai dengan pertumbuhan cacing tanah (Siddique, 2005). Tanah yang kaya bahan organik akan lebih banyak dihuni oleh biota tanah salah satunya cacing tanah (Hanafiah et al. 2005).

Tabel 3. Hasil uji BNJ taraf $5 \%$ pengaruh aplikasi asam humat terhadap populasi cacing tanah pengamatan 90 HST di pertanaman jagung (Zea mays L.).

\begin{tabular}{cc}
\hline Perlakuan & Populasi Cacing Tanah (ekor $\mathbf{~ m}^{-2}$ ) \\
\hline Tanpa aplikasi asam humat $\left(\mathrm{H}_{0}\right)$ & $25(4) \mathrm{b}$ \\
Aplikasi asam humat $15 \mathrm{~kg} \mathrm{ha}^{-1}\left(\mathrm{H}_{1}\right)$ & $37(6) \mathrm{ab}$ \\
Aplikasi asam humat $30 \mathrm{~kg} \mathrm{ha}^{-1}\left(\mathrm{H}_{2}\right)$ & $56(7) \mathrm{a}$ \\
\hline BNJ 5\% & 2
\end{tabular}

Keterangan : Angka yang diikuti oleh huruf yang sama tidak berbeda nyata dengan uji BNJ pada taraf $5 \%$; angka dalam kurung menunjukkan nilai transformasi $(\sqrt{x}+0,5)$.

Hasil penelitian menunjukkan bahwa populasi (Tabel 4) cacing tanah pada pengamatan $50 \mathrm{HST}$ lebih tinggi pada lahan yang diberi perlakuan pemupukan fosfat dibanding lahan yang tidak diberi perlakuan pepupukan fosfat. Pemupukan fosfat yang mengandung unsur hara $P$ akan membuat kondisi tanah menjadi lebih mendukung sehingga aktivitas organisme tanah seperti cacing akan meningkat. Populasi cacing tanah dapat bertambah karena disebabkan oleh berbagai faktor, seperti faktor makanan dan kecocokan pada kondisi dari tanah tempat tinggal dan hidupnya (Dwiastuti dan Suntoro, 2009).

Tabel 4. Hasil uji BNJ taraf $5 \%$ pengaruh pemupukan fosfat terhadap populasi cacing tanah pada pengamatan 50 HST di pertanaman jagung (Zea mays L.).

\begin{tabular}{cc} 
Perlakuan & Populasi Cacing Tanah (ekor $\left.\mathbf{~ m}^{-2}\right)$ \\
\hline Tanpa pupuk TSP $\left(P_{0}\right)$ & $1(1,05) \mathrm{ab}$ \\
Pupuk TSP $100 \mathrm{~kg} \mathrm{ha}^{-1}\left(\mathrm{P}_{1}\right)$ & $1(0,96) \mathrm{b}$ \\
Pupuk TSP $200 \mathrm{~kg} \mathrm{ha}^{-1}\left(\mathrm{P}_{2}\right)$ & $1(1,05) \mathrm{ab}$ \\
Pupuk TSP $300 \mathrm{~kg} \mathrm{ha}^{-1}\left(\mathrm{P}_{3}\right)$ & $5(1,4) \mathrm{a}$ \\
\hline BNJ 5\% & 0,36
\end{tabular}

Keterangan : Angka yang diikuti oleh huruf yang sama tidak berbeda nyata dengan uji BNJ pada taraf $5 \%$; angka dalam kurung menunjukkan nilai transformasi $(\sqrt{x}+0,5)$.

Hasil pengamatan cacing tanah berdasarkan kunci determinasi identifikasi cacing tanah dan deskripsi cacing tanah Blakemore, (2002) menunjukkan bahwa jenis cacing tanah pada lahan penelitian pertanaman jagung (Zea mays L.) di BPTP Natar, Lampung Selatan merupakan cacing tanah dengan golongan famili Glossoscolicidae. Cacing tanah yang diperoleh memiliki ciri-ciri jumlah segmen yaitu 190 segmen, lekukan antar segmen pada klitelum (alat reproduksi) terlihat jelas dan terletak pada segmen ke 14 (Gambar 1), bentuk prostomium (alat mulut) tipe prolobus (Gambar 2), dan setae (bulu halus) berpola lumbrisin (Gambar 3).

Berdasarkan hasil identifikasi cacing tanah pada penelitian ini menunjukkan bahwa jenis cacing tanah tergolong genus Pontoscolex sp.. Cacing tanah genus 
Pontoscolex sp. termasuk dalam famili Glossoscolecidae, cacing ini memiliki ciri-ciri klitelum yang terletak pada segmen $\mathrm{ke}^{-1} 4$, memiliki setae dengan pola lumbrisin, dan tipe prostomium yaitu prolobus [12].

Cacing tanah dewasa yang diidentifikasi banyak diperoleh pada lapisan olah (top soil) yaitu kedalaman $0-20 \mathrm{~cm}$ dibandingkan dengan sisanya yaitu kedalaman 20-30 cm, sehingga dapat dikatakan cacing tanah tersebut masuk kedalam kelompok cacing epigeik. Hal ini disebabkan oleh lapisan olah merupakan lapisan tanah yang kaya akan bahan organik, sehingga cacing tanah lebih banyak pada lapisan tersebut. Cacing tipe epigeik merupakan cacing yang tinggal dipermukaan tanah atau lapisan organik. Cacing tipe epigeik berperan dalam penghancuran seresah dan transformasi bahan organik, tetapi tidak aktif dalam penyebaran seresah. Ciri lain cacing ini adalah tidak membuat lubang di dalam tanah (Hairiah et al. 2004).

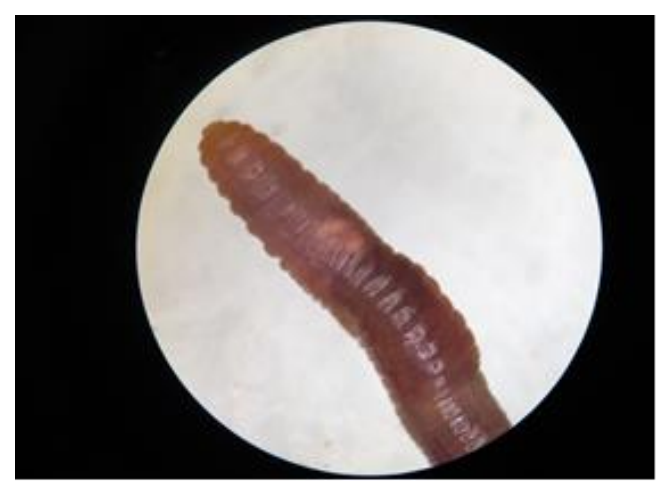

Gambar 1. Identifikasi cacing tanah berdacarkan latalk klitelum (alat reproduksi).

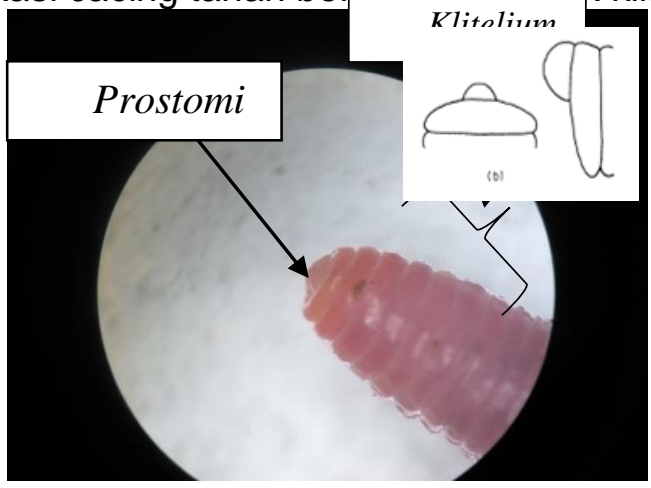

Gambar 2. Identifikasi cacing tanah berdasarkan prostomium (alat mulut) yaitu tipe prolobus.

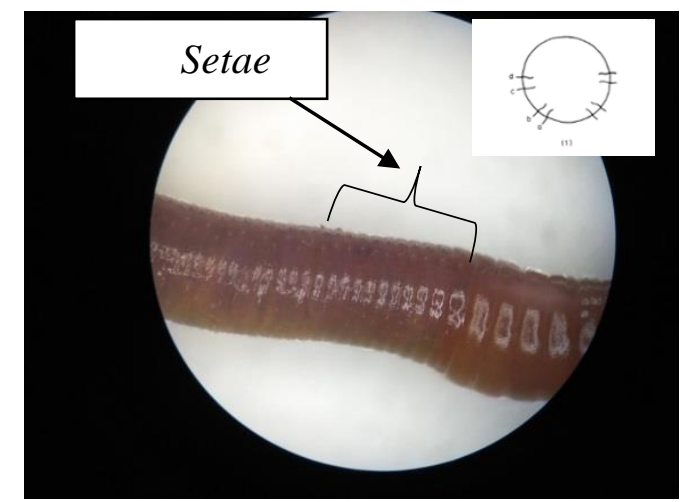

Gambar 3. Identifikasi cacing tanah berdasarkan setae (bulu halus) yaitu pola lumbrisin.

Grafik populasi dan biomassa cacing tanah (Gambar 4 \& 5) menunjukkan hasil yang rendah pada pengamatan $14 \mathrm{HST}$ dan $50 \mathrm{HST}$, kemudian mengalami 
peningkatan pada pengamatan $90 \mathrm{HST}$. Masih rendahnya tingkat populasi dan biomassa cacing tanah pada pengamatan 14 HST dan 50 HST diduga disebabkan karena relatif singkatnya pemberian asam humat terhadap waktu pengamatan, sehingga pemberian asam humat belum termanfaatkan secara optimal. Relatif singkatnya waktu pemberian asam humat belum cukup untuk memperbaiki struktur tanah. Struktur tanah yang baik dapat mempengaruhi lingkungan mikroorganisme seperti kadar air tanah, $\mathrm{pH}$ tanah, kelembaban tanah, dan suhu tanah (Baskoro, 2010). Meningkatnya populasi dan biomassa cacing tanah pada pengamatan 90 HST diduga karena kondisi lingkungan lebih sesuai untuk perkembangbiakan cacing tanah dibandingkan pada pengamatan 14 HST dan 50 HST. Kondisi lingkungan seperti kadar air tanah dan suhu tanah pada pengamatan 90 HST lebih mendukung keberadaan cacing tanah.

Hasil uji korelasi (Tabel 5) menunjukkan bahwa variabel pendukung seperti pH tanah memiliki korelasi yang nyata dengan populasi cacing tanah pada pengamatan 14 HST. Suhu tanah (oC), kadar air tanah (\%), dan C-organik tanah (\%) tidak memiliki korelasi yang nyata dengan populasi cacing tanah dan biomassa cacing tanah pada pengamatan 14 HST, 50 HST, dan 90 HST. Selanjutnya, pertumbuhan vegetatif (tinggi tanaman dan jumlah daun), bobot kering brangkasan, produksi jagung tidak memiliki korelasi yang nyata dengan populasi cacing tanah dan biomassa cacing tanah.

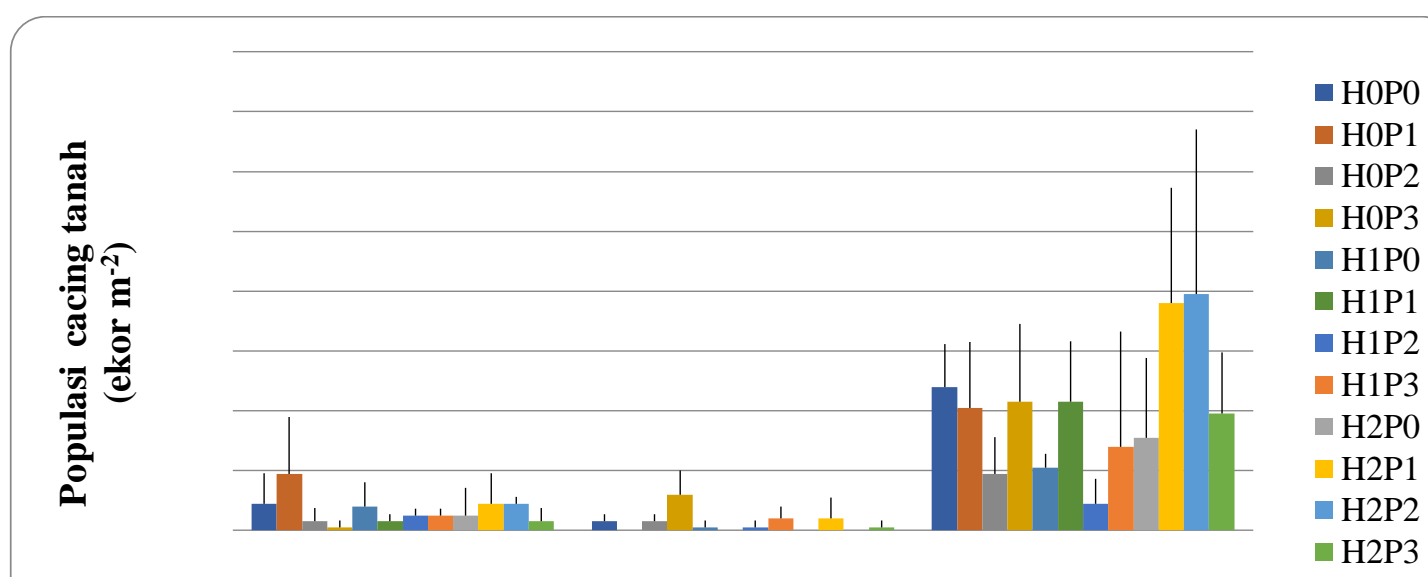

Waktu Pengamatan

Gambar 4. Populasi cacing tanah pada pengamatan $14 \mathrm{HST}, 50 \mathrm{HST}$, dan $90 \mathrm{HST}\left(\mathrm{H}_{0}=\right.$ tanpa asam humat; $\mathrm{H}_{1}=$ aplikasi asam humat $15 \mathrm{~kg}^{-1} ; \mathrm{H}_{2}=$ aplikasi asam humat $30 \mathrm{~kg} \mathrm{ha}^{-1} ; \mathrm{P}_{0}=$ tanpa pupuk TSP; $\mathrm{P}_{1}=$ pupuk TSP $100 \mathrm{~kg} \mathrm{ha}^{-1} ; \mathrm{P}_{2}=$ pupuk TSP $200 \mathrm{~kg} \mathrm{ha}^{-1} ; \mathrm{P}_{3}=$ pupuk TSP $\left.300 \mathrm{~kg} \mathrm{ha}^{-1}\right)$. 


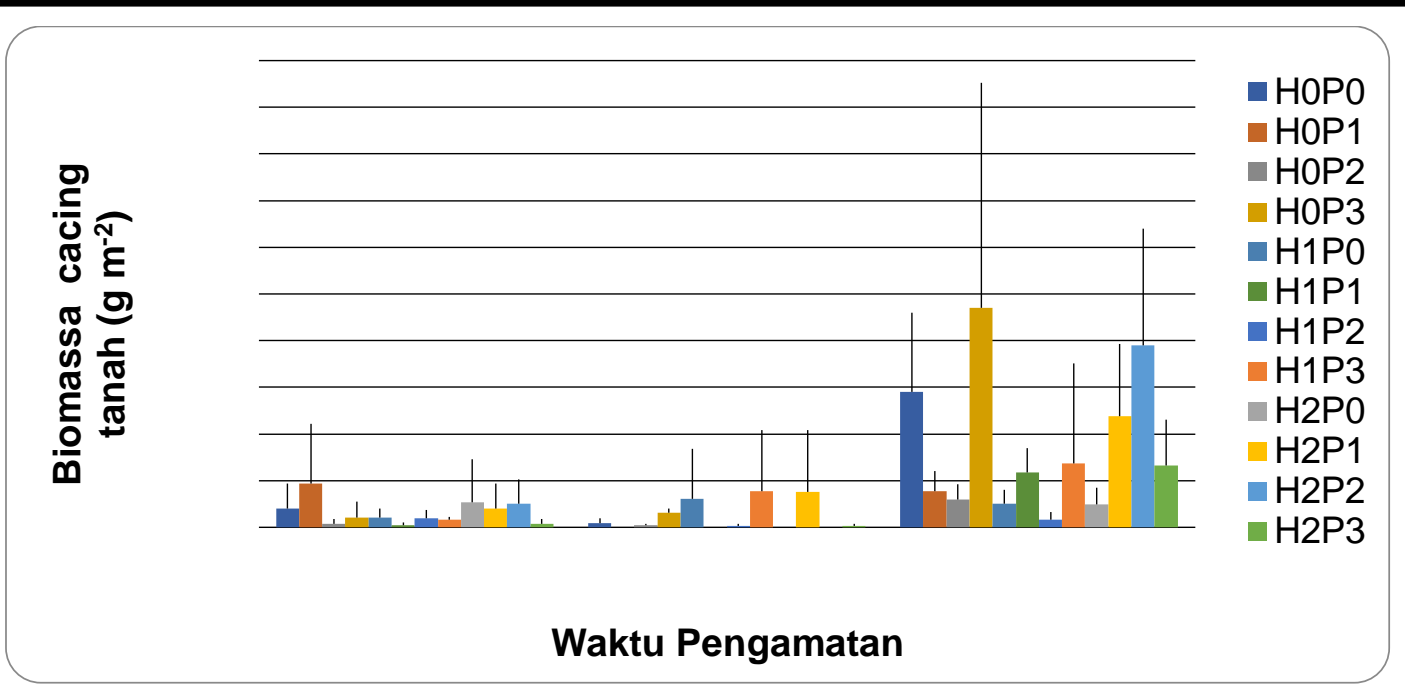

Gambar 5. Biomassa cacing tanah pada pengamatan $14 \mathrm{HST}, 50 \mathrm{HST}$, dan $90 \mathrm{HST}\left(\mathrm{H}_{0}=\right.$ tanpa asam humat; $H_{1}=$ aplikasi asam humat $15 \mathrm{~kg} \mathrm{ha}^{-1} ; \mathrm{H}_{2}=$ aplikasi asam humat $30 \mathrm{~kg} \mathrm{ha}^{-1} ; \mathrm{P}_{0}=$ tanpa pupuk TSP; $\mathrm{P}_{1}=$ pupuk TSP $100 \mathrm{~kg} \mathrm{ha}^{-1} ; \mathrm{P}_{2}=$ pupuk TSP $200 \mathrm{~kg} \mathrm{ha}^{-1} ; \mathrm{P}_{3}=$ pupuk TSP $300 \mathrm{~kg} \mathrm{ha}^{-1}$ ).

Berdasarkan uji korelasi (Tabel 5), menunjukkan bahwa $\mathrm{pH}$ tanah pada pengamtan 14 HST memberikan korelasi yang nyata terhadap populasi cacing tanah, sedangkan pada pengamatan 50 HST dan 90 HST memberikan korelasi yang tidak nyata terhadap populasi cacing tanah. Pada pengamatan $14 \mathrm{HST}, \mathrm{pH}$ tanah memberikan korelasi negatif terhadap populasi cacing tanah. Hal ini diduga karena perlakuan yang diberikan belum memberikan kontribusi yang optimal ke dalam tanah. Kemasaman tanah sangat mempengaruhi populasi dan aktivitas cacing tanah sehingga menjadi faktor pembatas penyebarannya. Tingkat kemasaman tanah yang dibutuhkan oleh cacing tanah adalah pada pH sekitar 6 - 7,2 (Handayanto dan Hairiah2009).

Tabel 5. Korelasi antara $\mathrm{pH}$, suhu, kadar air, C-organik tanah, dan produksi dengan populasi cacing tanah (ekor $\left.\mathrm{m}^{-2}\right)$ dan biomassa cacing tanah $\left(\mathrm{g} \mathrm{m}^{-2}\right)$ pada pertanaman jagung (Zea mays L.).

\begin{tabular}{|c|c|c|c|c|c|c|}
\hline \multirow{3}{*}{ Variabel Pendukung } & \multicolumn{6}{|c|}{ Koefisien Korelasi (r) } \\
\hline & \multicolumn{3}{|c|}{ Populasi Cacing (ekor m } & \multicolumn{3}{|c|}{ Biomassa Cacing $\left(\mathrm{g} \mathrm{m}^{-2}\right)$} \\
\hline & 14 HST & 50 HST & 90 HST & 14 HST & 50 HST & 90 HST \\
\hline $\mathrm{pH}$ tanah & $-0,50 *$ & $-0,19$ tn & $-0,11$ th & $-0,33$ tn & $-0,21$ th & $-0,10$ tn \\
\hline Suhu $\left({ }^{\circ} \mathrm{C}\right)$ & $-0,17 \mathrm{tn}$ & $-0,24$ tn & $-0,03$ tn & 0,03 tn & $-0,20 \mathrm{tn}$ & $-0,02$ tn \\
\hline Kadar air (\%) & 0,04 tn & 0,10 tn & $-0,12$ tn & 0,00 tn & 0,16 tn & $-0,06 \mathrm{tn}$ \\
\hline C-organik (\%) & $-0,32$ tn & 0,06 tn & $-0,29$ tn & $-0,30$ tn & 0,28 tn & ${ }^{-1}, 36 \mathrm{tn}$ \\
\hline Tinggi Tanaman (cm) & 0,22 tn & $-0,35$ tn & - & 0,27 tn & $-0,03$ tn & - \\
\hline Jumlah Daun & $-0,13$ tn & 0,15 tn & - & 0,04 tn & $-0,06$ tn & - \\
\hline $\begin{array}{l}\text { Bobot Brangkasan } \\
\qquad(\mathrm{kg})\end{array}$ & - & - & $-0,06$ tn & - & - & 0,07 tn \\
\hline Produksi (t ha $\left.{ }^{-1}\right)$ & - & - & $-0,12$ tn & - & - & 0,00 tn \\
\hline
\end{tabular}




\section{SIMPULAN}

Berdasarkan hasil penelitian dapat disimpulkan bahwa populasi cacing tanah pengamatan 50 HST lebih tinggi pada lahan yang tidak diaplikasikan asam humat. Sedangkan, pada pengamatan 90 HST populasi cacing tana lebih tinggi pada lahan yang diaplikasikan asam humat $30 \mathrm{~kg} \mathrm{ha}^{-1}$. Populasi cacing tanah pengamatan 50 HST lebih tinggi pada lahan dengan perlakuan pemupukan fosfat pada dosis $300 \mathrm{~kg}$ $\mathrm{ha}^{-1}$. Tidak terdapat interaksi antara aplikasi asam humat dan pemupukan fosfat terhadap populasi dan biomassa cacing tanah pada semua pengamatan pada pertanaman jagung. Terdapat hubungan antara $\mathrm{pH}$ dengan populasi cacing tanah pada pengamatan 14 HST. Sedangkan, tidak terdapat hubungan antara suhu, kadar air, C-organik tanah, pertumbuhan vegetatif, bobot kering brangkasan, dan produksi tanaman jagung terhadap populasi dan biomassa cacing tanah.

\section{DAFTAR PUSTAKA}

Baskoro, D. P. T. 2010. Pengaruh pemberian bahan humat dan kompos sisa tanaman terhadap sifat fisik tanah dan produksi ubi kayu. Jurnal Tanah dan Lingkungan 12(1): $9^{-1} 4$.

Blakemore, R.J. 2002. Cosmopolitan Eartworms- an Eco-Taxonomic Guide to the Peregrine Species of the World. Verm Ecology. Kippax. Australia.

Dewi, E.C. 2014. Pengaruh Berbagai Cara Pemberian Bahan Humat terhadap Produksi Ubi Jalar (Ipomoea batatas L.). [Skripsi], Institut Pertanian Bogor, Bogor.

Dwiastuti, S dan Suntoro. 2009. Eksistensi Cacing Tanah Pada Lingkungan Berbagai Sistem Budidaya Tanaman Di Lahan Berkapur. Universitas Sebelas Maret, Surakarta.

Fahmi, A., Syamsudin, S. N. H. Utami, dan B. Radjagukguk. 2009. Peran Pemupukan Fosfor dalam Pertumbuhan Tanaman Jagung (Zea mays L.) Di Tanah Regosol dan Latosol. Berita Biologi 9(6): 745-750.

Hairiah, K., D. Suprayogo., Widianto, Berlian, E. Suhara., A. Mardiastuning., R. H. Widodo., C. Prayogo., dan Rahayu. 2004. Alih Guna Lahan Hutan menjadi Lahan Pertanian: Ketebalan Serasah, Populasi Cacing Tanah, dan Makroporositas Tanah. AGRIVITA 26(1): 68-80.

Hanafiah, A. K., I. Anas, A. Napoleon, dan N. Ghoffar. 2005. Biologi Tanah: Ekologi dan Makrobiologi Tanah. PT Raja Grafindo Persada, Jakarta.

Handayanto, E., dan K. Hairiah. 2009. Biologi Tanah Landasan Pengelolaan Tanah Sehat. Pustaka Adipura, Yogyakarta.

Ihdaryanti, M.A. 2011. Pengaruh Asam Humat dan Cara Pemberiannya terhadap Pertumbuhan dan Produktivitas Tanaman Padi (Oryza sativa). Skripsi, Institut Pertanian Bogor. Bogor.

Maulana, D., Sarno, Nurmiaty, Y. 2014. Pengaruh Aplikasi Asam Humat dan Pemupukan Fosfor Terhadap Serapan Unsur Hara P dan K Tanaman Tomat (Lycopersicum esculentum). Jurnal Agtorek Tropika 2(2): 302-305.

Muchtar. 2015. Pengelolaan Lahan Kering Masam Berkelanjutan Di KP. Taman Bogo. Balai Penelitian Tanah, Balai Besar Penelitian dan Pengembangan Sumberdaya Lahan Pertanian, Balitbangtan, Bogor.

Salamah, M. H., A. Niswati, Dermiyati, dan S. Yusnaini. 2016. Pengaruh Sistem Olah Tanah dan Pemberian Mulsa Bagas terhadap Populasi dan Biomassa Cacing 
Tanah pada Lahan Pertanian Tebu Tahun Ke-5. Jurnal Agrotek Tropika 4(3): 222-227.

Sari, Y. K.., A. Niswati, M.A.S. Arif, dan S. Yusnaini. 2015. Pengaruh Sistem Olah Tanah dan Aplikasi Herbisida terhadap Populasi dan Biomassa Cacing Tanah pada Pertanaman Ubi Kayu (Manihot utilissima). Jurnal Agrotek Tropika 3(3): $422-426$.

Siddique, J.2005. Growth and reproduction of earthworm (Eisenia fetida) in different organic media. Journal of Zoology 37(3): 211 - 214.

Tan, K.H. 2014. Humic Matter in Soil and the Environment: Principles and Controversies., 2th Edition. Apple Academic Press, Inc. Oakville. Canada, 495 hlm. 